\title{
INTERNATIONAL DETERMINANTS OF HUMAN RIGHTS AND WELFARE: LAW, WEALTH OR CULTURE
}

\author{
Frank B. Cross*
}

\section{INTRODUCTION}

The relative protection of fundamental human rights varies considerably among nations, as does the social welfare of individuals. If the sources of this variance can be identified, we may better be able to define and implement policies to advance human rights and welfare across the globe. This article represents a first step toward ascertaining the determinants of national levels of rights and well-being. I examine three potential factors influencing levels of rights and welfare - the prominence of the rule of law, relative wealth, and cultural difference. Various studies have considered these factors and sought to measure their effect, but these studies have considered the factors individually rather than jointly.

For purposes of this article, human rights are defined as the type of individualist negative rights found in the Bill of Rights and the U.S. Constitution. This definition includes such rights as the right to vote in democratic elections, freedom of speech and belief, freedom from imprisonment without due process of law, and analogous rights. I define human welfare as a measure of material well-being sometimes called positive economic rights, either for the average citizen or for the poorest segment of society. Additional detail about these definitions is provided below in my discussion of methodology.

One potential source of human rights and welfare is the prominence of the rule of law. The potential significance of law is most apparent with respect to the classical negative human rights, because such rights are legally defined and legally enforced against an infringing government. Presumably, a nation that constitutionally guarantees basic rights (such as freedom of speech or freedom from unreasonable searches and seizures) would maintain higher levels of such rights. ${ }^{1}$ Other legal factors also may influence the measure of negative human rights throughout the world. Gerald Scully has found an association between common law nations and higher levels of freedom. ${ }^{2}$ Law and independent courts may be considered central to the

* Professor of Business Regulation, University of Texas.

1. Of course, constitutional guarantees are not self-enforcing. Nor are such guarantees exogenous. The content of a constitution is surely affected by a nation's culture, its wellbeing, and its legal structure. Consequently, my study focuses not so much on the written content of the guarantee as on the mechanisms through which such rights may be advanced.

2. GERALD W. SCULlY, CONSTTTUTIONAL ENVIRONMENTS AND ECONOMIC GROWTH 148-65 (1992). Scully cites a number of features of the English common law system that promote human rights, including the "[e]qual protection and equal status of the litigants and 
creation and protection of rights. ${ }^{3}$ In addition to the substantive content of law, procedural features, such as the position of lawyers, may also influence the protection of human rights. Terence Halliday reports considerable anecdotal evidence of lawyers advancing human rights in different international regimes. ${ }^{4}$ One might, therefore, expect a large number of lawyers to enhance the advancement of such rights, as some existing research has found. ${ }^{5}$

Law may also advance material human welfare insofar as it provides a counterweight to the power of the wealthiest societal group. While most economic systems enable the wealthy or otherwise empowered to have their way, legal systems may provide a brake that limits the exercise of this power. In the United States, one cannot purchase an actual slave, regardless of one's wealth and inclinations. Law may also have a broader influence. For example, lawyers can play a significant role in defining society's values. ${ }^{6}$ This connection seems weaker, though, than the likely association of law and negative human rights. Katarina Tomaševski suggests that the rule of law can contribute more to the protection of human rights than to overall material welfare. ${ }^{7}$ Some suggest that the law's devotion to the protection of negative human rights might actually undermine human welfare. ${ }^{8}$

strict judicial independence [to] circumscribe the coercive power of government." $l d$. at 151 . His cross-national empirical analysis indeed found that freedom was greater in common law countries and that the differences were "relatively large and are statistically significant at well above the 1 percent level." Id. at 161 .

3. See, e.g., Brian Z. Tamanaha, The Lessons of Law-and-Development Studies, 89 AM. J. INT'L L. 470 (1995). Tamanaha notes that the law can be used as a "means of social engineering" for achieving "development objectives." Id. at 473 . He further observes that when courts are "weak or irrelevant[,]" elites can exercise power more arbitrarily. ld. at 474. He concludes that law may be helpful or even necessary to economic and political development, but that legal development is not itself sufficient to achieve these ends. $I d$. at 483-84.

4. Terence C. Halliday, Legal Professions and the State: Neocorporatist Variations on the Pluralist Theme of Liberal Democracies, in 3 LAWYERS IN SOCIETY: COMPARATIVE THEORIES 375 (R.L. Abel \& P.S.C. Lewis eds., 1989). Halliday's examples include the resistance to Franco's fascism on the part of Spanish lawyers, the fight of Argentine lawyers against military dictatorship, and other cases. Id. at 404-05.

5. Frank B. Cross, The First Thing We Do, Let's Kill All the Economists: An Empirical Evaluation of the Effect of Lawyers on the United States Economy and Political System, 70 TEX. L. REV. 645, 676-78 (1992). The study found a statistically significant association between lawyer numbers and both civil liberties and democracy, though lawyers did not explain a high percentage of the variance in these features. $I d$. at 678 .

6. See Philip S. Stamatakos, The Bar in America: The Role of Elitism in a Liberal Democracy, 26 U. MiCH. J.L. REF. 853 (1993).

7. Katarina Tomaševski, Monitoring Human Rights Aspects of Sustainable Development, 8 AM. U. J. INT'L L. \& POL'Y 77, 85 (1992).

8. See, e.g., ZEHRA F. ARAT, DEMOCRACY AND HuMAN RIGHTS IN DEVELOPING COUNTRIES (1991). Arat observes that "socioeconomic rights are often considered as group rights that can be maintained only at the expense of individual rights (civil-political rights), or vice versa." Id. at 3-4. He observes that communitarians believe that negative rights interfere 
Another potential source of human rights and welfare is the level of national wealth. The richer a nation, the greater its mean level of material well-being, which may produce a higher level of welfare for the median and poorest groups as well, either through a trickle down of free market benefits or via greater government transfer payments and other public welfare expenditures. Wealth may also contribute to human rights, in that wealthier societies with relatively less concern for material necessities might place greater value on individual rights. Lee Kuan Yew, Singapore's former Prime Minister declared that: "When you are hungry, when you lack basic services, freedom, human rights and democracy do not add up to much." In a Maslovian hierarchy of needs, pursuit of some minimal level of wealth would precede the quest for protection of human rights. ${ }^{10}$ One review suggests that civil and political rights have generally expanded in parallel with the expansion of national wealth." The association of wealth and human rights has been empirically suggested in prior research. ${ }^{12}$ Some suggest that the positive social rights are an essential prerequisite to individual rights. ${ }^{13}$

Yet another influence on human rights and welfare is local culture. Indeed, some maintain that there are no universal rights and that all concepts of rights are culture-based. ${ }^{14} \mathrm{~A}$ variety of authors have claimed that

with positive rights, while classical liberals reject positive rights as requiring a compromise of negative rights. Id. at 4 . While Arat believes that the two categories of rights are in some tension, he does not find the conflict ineluctable. Rather, he calls for a balanced promotion of both sets of rights. Id. at 8 .

9. Philip Shenon, Singapore, the Tiger Whose Teeth Are Not Universally Scorned, N.Y. TIMES, Apr. 10, 1994, at 5. Adamantia Pollis makes the very broad claim that "[a]ll third world countries espouse the priority of economic and social rights over civil and political rights." Adamantia Pollis, Liberal, Socialist, and Third World Perspectives of Human Rights, in TOWARd a Human Rights Framework 20 (Peter Schwab \& Adamantia Pollis eds., 1982).

10. See Abraham H. Maslow, Motivation AND PERSONAlity 35-46 (2d ed. 1970) (suggesting that primary needs are physiological).

11. Ronald St. J. MacDonald, Book Review, 86 AM. J. INT'L L. 192 (1992) (reviewing CONSTITUTIONALISM AND RIGHTS: THE INFLUENCE OF THE UNITED STATES CONSTITUTION ABROAD (Louis Henkin \& Albert J. Rosenthal eds., 1990)). He cites one commentator who notes Africa as an example of a region where "pressing economic and social development needs support economic-based rights over civil and political freedoms." Id. at 195.

12. See R.D. McKinlay \& A.S. Cohan, A Comparative Analysis of the Political and Economic Performance of Military and Civilian Regimes, 8 COMP. POL. 1 (1975); Partha Dasgupta \& Martin Weale, On Measuring the Quality of Life, 20 WORLD DEV. 19 (1992); Neil J. Mitchell \& James M. McCormick, Economic and Political Explanations of Human Rights Violations, 40 WORLD POL. 476 (1988).

13. See ARAT, supra note 8 , at 4.

14. This thesis is reviewed by numerous articles in ABDULLAHI AHMED AN-NA' IM, HuMAN RIgHTS IN CROSS-CULTURAL PERSPECTIVES: A QUEST FOR CONSENSUS (1992). See also HUMAN RIGHTS IN THE AMERICAS: THE STRUGGLE FOR CONSENSUS (Alfred T. Hennelly \& John Langan eds., 1982) (presenting perspectives on human rights from various traditions, both religious and secular philosophical); AsIAN PERSPECTIVES ON HUMAN RIGHTS (Claude E. Welch, Jr. \& Virginia A. Leary eds., 1990) (discussing human rights concepts from the 
democracy is contingent upon cultural conditions to a considerable degree. ${ }^{15}$ Other individualist human rights are also affected by cultural traditions. ${ }^{16}$ Without entering that debate over the ethnocentrism of specific rights, this study investigates whether the actual protection of traditional Western individual rights is, in fact, culture-based as so often assumed. One can discern the extent to which protection of these rights is culturally based and then draw one's own conclusions regarding the value of the rights.

Culture may also influence human welfare, as some cultures presumably are more altruistic and egalitarian rather than individualist. Mark Casson has observed that culture may influence human welfare, as Eastern economies function differently from those of the West, a feature that may influence overall economic growth, distribution of income, or the level of government transfer payments. ${ }^{17}$ One must take care to escape the temptation of sociologically ascribing any and all differences to culture, however. One author found that cultural factors had less effect on welfare than did the country's political and economic institutions. ${ }^{18}$ Culture may be a product, rather than the cause, of a nation's law and wealth.

Given the theoretical basis for expecting law, wealth, or culture to affect human rights and welfare, investigation of the empirics is in order. Which factors matter and how much do they matter? While these variables have interrelationships among themselves, the multiple regression format is designed to isolate independent effects of each variable. The following study uses this approach to search for an association between measures of law,

Asian philosophical tradition); ALISON DUNDES RENTELN, INTERNATIONAL HUMAN RIGHTS: UNIVERSALISM VERSUS RELATIVISM (1990) (suggesting that there is no philosophical basis for universal notions of human rights). The culture-dependence of human rights also has been challenged from a philosophical perspective. See Raimundo Panikkar, Is the Notion of Human Rights a Western Concept?, 120 DIOGENES 75 (1982) (suggesting that human rights are fundamental to human life itself). Adamantia Pollis begins her essay on human rights by stating that "[h]uman rights, both their philosophic and/or theoretical formulation and their practice, are rooted in the specifics of particular societies and civilizations." Pollis, supra note 9 , at 1 .

15. See The Civic Culture Revisited (Gabriel A. Almond \& Sidney Verba eds., 1980) (suggesting that certain attributes called civic culture are central to democracy); MARTIN C. NeEdler, The Problem OF DemoCRACY IN LATIN AMERICA (1987) (suggesting that traditional Latin American culture is inconsistent in some respects with democracy); Claudio Véliz, THE CENTRALIST TRADITION OF LATIN AMERICA (1980) (contending that traditional Latin American culture conflicts with democratic approaches).

16. See, e.g., Abdul Aziz Said, Human Rights in Islamic Perspectives, in HuMan Rughts: Cultural and IdeOlogical PersPectives 86 (Adamantia Pollis \& Peter Schwab eds., 1979) (suggesting that individualistic negative rights are inconsistent with Islamic culture).

17. Mark Casson, Cultural Determinants of Economic Performance, 17 J. COMP. ECON. 418 (1993).

18. See Marc M. Lindenberg, The Human Development RaCE: IMPROVING the QUALITY OF LIFE IN DEVELOPING COUNTRIES (1993). 
wealth, and culture and a variety of established indices of human freedom and welfare. ${ }^{19}$

\section{Methodology}

Empirical investigation of the above associations requires a closer definition of terms. For wealth, gross national product is an accepted measure, and this study uses for its independent variable of wealth the per capita gross domestic product of the nation in 1985 (GDP85). For law, no such accepted proxy is available. Rather than attempt somehow to measure the substantive content of the law, this study uses the number of lawyers per capita as the proxy for the prominence of law in a nation (LAWPOP). The substantive content of the law may be relatively meaningless without the resources and procedures to enforce its terms, and lawyers are the primary resource. Culture also lacks a convenient proxy. While cultural effects might be modeled in different ways, this study divides the world into six cultural zones: East Asia, South Asia, Middle East, Africa, Latin America, and Europe. Nations are assigned to these groups geographically, with an eye to historic culture (e.g., the United States and Canada are assigned to the Europe category)..$^{20}$

For the dependent variables of human rights and social welfare, the study uses a variety of secondary sources that have sought to quantify these variables across nations. The human rights proxies include the following:

- POLRIGHT, a private organization's measure of such rights as democratic elections and the right to vote; ${ }^{21}$

- CIVLIB, a private organization's measure of civil liberties, such as freedom of speech and religion; 22

- HUMANA, a different private organization's measure of human rights, focusing on individual freedom but also including some positive rights of

19. There are inherent limitations to any quantitative analysis of human rights, not the least of which is variable measurement. See, e.g., Robert Justin Goldstein, The Limitations of Using Quantitative Data in Studying Human Rights Abuses, 8 HUM. RTS. Q. 607 (1986). Yet even Goldstein recognizes the value of quantitative approaches but merely cautions against allowing quantitation to supplant any qualitative analysis.

20. This geographic proxy for culture could be criticized, but many of the discussions of cultural influence on rights are explicitly geographic in their categorization (e.g., suggesting that Latin American or Middle Eastern culture may control negative human rights allowed). See supra notes 15-16. I would emphasize that my geographic breakdown does not imply any inherent cultural attributes of peoples. For example, one author suggests that traditional African cultures were respectful of human rights but that this tradition was destroyed by colonialism. Dunstan M. Wai, Human Rights in Sub-Saharan Africa, in HUMAN RIGHTS: CULTURAL AND IDEOLOGICAL PERSPECTIVES 115 (Adamantia Pollis \& Peter Schwab eds., 1979).

21. Data for this variable are taken from RAYMOND D. GASTIL, FREEDOM AROUND THE WORLD: FREEDOM AT ISSUE (1990).

22. Id. 
material welfare; ${ }^{23}$

- HUMFREED, the United Nations ranking of human rights, including primarily individual freedom and equality of rights; ${ }^{24}$ and

- DUEPROC, a private organization's rating of judicial rights, especially for criminal defendants. ${ }^{25}$

Some of these rankings have suffered criticism for bias, either ethnocentric or ideological. ${ }^{26}$ This article does not enter that debate but rather considers the conventionally established standards of individual liberty, which doubtless carry some value to many individuals. The proxies used to measure material social welfare including the following:

- HUMDEVI, the United Nations human development index intended to measure overall human welfare, including such factors as GDP, life expectancy, and literacy; ${ }^{27}$

- SOCWELF, the proportion of government revenues dedicated to social welfare expenditures; ${ }^{28}$

- QLIFERAN, a private organization's rating of overall quality of life, considering health, freedom, economics, and other factors; ${ }^{29}$

- PQLI, a private measure of quality of life intended to focus on the status of the poorest citizens, including factors such as literacy and infant mortality; ${ }^{30}$ and

- ECOSOC, a private organization's rating of overall median human welfare. ${ }^{31}$

The different sources have varying definitions of material well-being, but together they should capture the comparative material quality of life.

To identify any effects of GDP85, LAWPOP, or geographic culture on the dependent variables of human rights or social welfare, a regression model is fit as follows. For example, the equation for democratic rights is:

23. Data for this variable are taken from CHARLES HUMANA, WORLD HUMAN RIGHTS GUIDE (1992).

24. Data for this variable are taken from UNITED NATIONS DEVELOPMENT PROGRAMME, HUMAN DEVELOPMENT REPORT (1991).

25. Data for this variable are taken from MichaEl J. SULlivan, MEASURING GLOBAL VALUES (1991).

26. See, e.g., Lisa J. Bernt, Note, Measuring Freedom? The UNDP Human Freedom Index, 13 MICH. J. INT'L L. 720 (1992). For example, these traditional conceptions of rights are individualistic and do not admit of group rights, which have recently received considerable attention. See, e.g., Pollis, supra note 9, at 7.

27. Data for this variable are taken from UNITED NATIONS DEVELOPMENT PROGRAMME, HUMAN DEVELOPMENT REPORT (1990).

28. Data for this variable are taken from source cited supra note 25.

29. Data for this variable are taken from AGORA, INC., THE WORLD'S BEST (1986).

30. Data for this variable are taken from M.D. MORRIS, MEASURING THE CONDITION OF THE WORLD'S POOR: THE PHYSICAL QUALITY OF LIFE INDEX (1979).

31. Data for this variable are taken from source cited supra note 25. 
POLRIGHT $=\mathrm{B}_{1}$ LAWPOP $+\mathrm{B}_{2}$ GDP85 $+\mathrm{B}_{3}$ DEASIA + $\mathrm{B}_{4}$ DSASIA $+\mathrm{B}_{5}$ DLAMER $+\mathrm{B}_{6}$ DAFRICA $+\mathrm{B}_{7}$ DMEAST + $B_{8}$ DEUROPE

DEASIA, for example, is a dummy variable, coded as 1 if the culture is East Asian and 0 if not. $B_{3}$ is the estimated level of political rights in East Asia if the number of lawyers and amount of wealth were zero. The same equation is employed for each dependent variable in turn.

\section{RESULTS}

The first test involved the human rights variables. For three of these variables (POLRIGHT, CIVLIB, and DUEPROC), a lower score or negative correlation coefficient is "better" (reflecting a higher level of the freedom measured). The results of this test are displayed in Table 1. Significance levels are shown in parentheses below the coefficients. 
Table 1

Determinants of Human Freedom

\begin{tabular}{|c|c|c|c|c|c|}
\hline & POLRIGHT & CIVLIB & HUMANA & $\begin{array}{l}\text { HUM- } \\
\text { FREED }\end{array}$ & DUEPROC \\
\hline $\mathrm{N}$ & 65 & 65 & 59 & 54 & 55 \\
\hline $\mathbf{R}^{2}$ & .677 & .673 & .765 & .792 & .655 \\
\hline LAWPOP & $\begin{array}{c}-.437 \\
(.045)\end{array}$ & $\begin{array}{l}-.206 \\
(.211)\end{array}$ & $\begin{array}{l}1.936 \\
(.331)\end{array}$ & $\begin{array}{c}.218 \\
(.842)\end{array}$ & $\begin{array}{c}-.793 \\
(.380)\end{array}$ \\
\hline GDP85 & $\begin{array}{c}-.112 \\
(.165)\end{array}$ & $\begin{array}{l}-.135 \\
(.030)\end{array}$ & $\begin{array}{l}1.128 \\
(.123)\end{array}$ & $\begin{array}{c}.941 \\
(.021)\end{array}$ & $\begin{array}{l}-.578 \\
(.070)\end{array}$ \\
\hline East Asia & $\begin{array}{c}4.42 \\
(.000)\end{array}$ & $\begin{array}{c}4.01 \\
(.000)\end{array}$ & $\begin{array}{l}57.73 \\
(.000)\end{array}$ & $\begin{array}{c}9.54 \\
(.000)\end{array}$ & $\begin{array}{l}24.06 \\
(.000)\end{array}$ \\
\hline South Asia & $\begin{array}{c}2.95 \\
(.000)\end{array}$ & $\begin{array}{c}3.57 \\
(.000)\end{array}$ & $\begin{array}{l}56.75 \\
(.000)\end{array}$ & $\begin{array}{c}9.96 \\
(.000)\end{array}$ & $\begin{array}{l}22.98 \\
(.000)\end{array}$ \\
\hline $\begin{array}{l}\text { Latin } \\
\text { America }\end{array}$ & $\begin{array}{c}3.50 \\
(.000)\end{array}$ & $\begin{array}{c}3.61 \\
(.000)\end{array}$ & $\begin{array}{l}66.90 \\
(.000)\end{array}$ & $\begin{array}{l}15.67 \\
(.000)\end{array}$ & $\begin{array}{l}19.69 \\
(.000)\end{array}$ \\
\hline Africa & $\begin{array}{c}5.84 \\
(.000)\end{array}$ & $\begin{array}{c}4.62 \\
(.000)\end{array}$ & $\begin{array}{l}53.76 \\
(.000)\end{array}$ & $\begin{array}{c}9.58 \\
(.000)\end{array}$ & $\begin{array}{l}22.67 \\
(.000)\end{array}$ \\
\hline Mid East & $\begin{array}{c}5.26 \\
(.000)\end{array}$ & $\begin{array}{c}4.50 \\
(.000)\end{array}$ & $\begin{array}{l}42.63 \\
(.000)\end{array}$ & $\begin{array}{c}7.26 \\
(.000)\end{array}$ & $\begin{array}{l}20.67 \\
(.000)\end{array}$ \\
\hline Europe & $\begin{array}{c}2.51 \\
(.000)\end{array}$ & $\begin{array}{c}2.55 \\
(.000)\end{array}$ & $\begin{array}{l}81.90 \\
(.000)\end{array}$ & $\begin{array}{l}24.81 \\
(.000)\end{array}$ & $\begin{array}{l}14.53 \\
\mathbf{( . 0 0 0 )}\end{array}$ \\
\hline
\end{tabular}

The geographic definition of culture plainly has an overpowering effect on the level of human rights across nations. Europe consistently scores higher levels of measured rights in every scale. Differences among other regions are significant but vary by scale. Table 2 contains exemplary pairwise comparisons of various cultures for the variable POLRIGHT, with law and wealth held constant. The table provides P-Values for each pair of cultures with "<" or ">" signs to show the direction of a statistically significant difference. Thus, the " $<$ " sign below indicates that the Middle East has a lower level of political rights than South Asia, holding the other variables constant. 
Table 2

Political Rights by Culture

\begin{tabular}{|l|c|c|c|c|c|c|}
\hline & East Asia & South Asia & $\begin{array}{c}\text { Latin } \\
\text { America }\end{array}$ & Africa & Mid East & Europe \\
\hline East Asia & & .1075 & .2365 & .1036 & .3131 & $\mathbf{. 0 0 7 2 >}$ \\
\hline South Asia & & & .3583 & $.0001<$ & $.0022<$ & .5906 \\
\hline $\begin{array}{l}\text { Latin } \\
\text { America }\end{array}$ & & & & $.0001<$ & $.0031<$ & .1163 \\
\hline Africa & & & & & .3976 & $\mathbf{. 0 0 0 1 >}$ \\
\hline Mid East & & & & & & $\mathbf{. 0 0 0 2}>$ \\
\hline Europe & & & & & & \\
\hline
\end{tabular}

Law has a statistically significant positive effect on political rights but no other individual rights variable, once the cultural variables are entered. This result is contrary to expectations, as one might have expected a stronger effect on due process and other individual rights that generally require legal assistance for vindication. In all cases, the direction of the coefficient for law was associated with higher levels of freedom, which may suggest some positive effect.

Wealth has a statistically significant positive effect on civil liberties and the United Nations human rights ranking, but not on other variables. However, wealth has a positive association for all variables (negative coefficients are for variables for which lower numbers mean more liberty) and approaches statistical significance for all. This encouraging result suggests that individual rights gain greater respect as a nation grows economically. It seems to suggest that greater wealth and more lawyers consistently tend to promote greater respect for freedom.

The same methodology was used to test relative levels of human welfare, and results are reported in Table 2. One variable (ECOSOC) has an inverse direction between score and level of welfare such that smaller numbers reflect higher levels of welfare. 
Table 3

Determinants of Human Welfare

\begin{tabular}{|c|c|c|c|c|c|}
\hline & SOCWELF & HUMDEVI & QLIFERAN & PQLI & ECOSOC \\
\hline $\mathbf{N}$ & 57 & 63 & 64 & 63 & 64 \\
\hline $\mathbf{R}^{2}$ & .796 & .763 & .913 & .810 & .881 \\
\hline LAWPOP & $\begin{array}{c}.050 \\
(.045)\end{array}$ & $\begin{array}{c}.046 \\
(.070)\end{array}$ & $\begin{array}{c}2.21 \\
(.032)\end{array}$ & $\begin{array}{c}3.39 \\
(.088)\end{array}$ & $\begin{array}{l}-3.06 \\
(.230)\end{array}$ \\
\hline GDP85 & $\begin{array}{c}.037 \\
(.000)\end{array}$ & $\begin{array}{c}.038 \\
(.000)\end{array}$ & $\begin{array}{c}2.54 \\
(.000)\end{array}$ & $\begin{array}{c}2.92 \\
(.000)\end{array}$ & $\begin{array}{c}-6.51 \\
(.000)\end{array}$ \\
\hline East Asia & $\begin{array}{c}.590 \\
(.000)\end{array}$ & $\begin{array}{c}.561 \\
(.000)\end{array}$ & $\begin{array}{l}20.79 \\
(.000)\end{array}$ & $\begin{array}{l}61.14 \\
(.000)\end{array}$ & $\begin{array}{l}82.29 \\
(.000)\end{array}$ \\
\hline South Asia & $\begin{array}{c}.525 \\
(.000)\end{array}$ & $\begin{array}{c}.487 \\
(.000)\end{array}$ & $\begin{array}{l}21.27 \\
(.000)\end{array}$ & $\begin{array}{l}56.69 \\
(.000)\end{array}$ & $\begin{array}{l}100.9 \\
(.000)\end{array}$ \\
\hline $\begin{array}{l}\text { Latin } \\
\text { America }\end{array}$ & $\begin{array}{c}.579 \\
(.000)\end{array}$ & $\begin{array}{c}.557 \\
(.000)\end{array}$ & $\begin{array}{l}20.71 \\
(.000)\end{array}$ & $\begin{array}{l}59.13 \\
(.000)\end{array}$ & $\begin{array}{l}86.26 \\
(.000)\end{array}$ \\
\hline Africa & $\begin{array}{c}.349 \\
(.000)\end{array}$ & $\begin{array}{c}.337 \\
(.000)\end{array}$ & $\begin{array}{l}14.28 \\
(.000)\end{array}$ & $\begin{array}{l}32.78 \\
(.000)\end{array}$ & $\begin{array}{l}103.7 \\
(.000)\end{array}$ \\
\hline Mid East & $\begin{array}{c}.490 \\
(.000)\end{array}$ & $\begin{array}{c}.499 \\
(.000)\end{array}$ & $\begin{array}{l}12.74 \\
(.000)\end{array}$ & $\begin{array}{l}45.04 \\
(.000)\end{array}$ & $\begin{array}{l}85.51 \\
(.000)\end{array}$ \\
\hline Europe & $\begin{array}{c}.596 \\
(.000)\end{array}$ & $\begin{array}{c}.567 \\
(.000)\end{array}$ & $\begin{array}{l}31.42 \\
(.000)\end{array}$ & $\begin{array}{l}62.93 \\
(.000)\end{array}$ & $\begin{array}{l}76.46 \\
(.000)\end{array}$ \\
\hline
\end{tabular}

As in the case of human rights, regional culture has a strong effect on material well-being. Europe consistently has higher levels of welfare for these dependent variables, even independent of the measured effects of wealth and law. The difference seen here between Europe, East Asia, and the other regions is much smaller, though, than in the freedom measures. Table 4 contains the significance levels for pairwise comparisons of the variable PQLI among the cultures. Statistically significant differences were found only for Africa or the Middle East as compared with other regions. Thus, although the nations of Africa are generally poor, these countries are not providing well for their poorest people, even accounting for their resource constraints. There are no significant differences among the cultures of East Asia, South Asia, Latin America, and Europe on this scale. 
Table 4

Physical Quality of Life Index by Culture

\begin{tabular}{|l|l|l|c|c|c|c|}
\hline & East Asia & South Asia & $\begin{array}{c}\text { Latin } \\
\text { America }\end{array}$ & Africa & Mid East & Europe \\
\hline East Asia & & .5579 & .7591 & $.0003<$ & $.0255<$ & .7600 \\
\hline South Asia & & & .6249 & $.0001<$ & $.0599<$ & .3669 \\
\hline $\begin{array}{l}\text { Latin } \\
\text { America }\end{array}$ & & & & $.0001<$ & $.0050<$ & .4673 \\
\hline Africa & & & & & $.0391<$ & $.0001>$ \\
\hline Mid East & & & & & & $.0014>$ \\
\hline Europe & & & & & & \\
\hline
\end{tabular}

Somewhat surprisingly, the rule of law has a pronounced association with material well-being. The number of lawyers correlated significantly with SOCWELF and QLIFERAN and was significant at the .10 level for HUMDEVI and PQLI. The correlation is consistently positive. Contrary to expectation, the measured positive effect of lawyers on material welfare appears even greater than the measured effect on freedom.

Less surprisingly, national wealth also has a strong positive correlation with each material welfare variable. This is not simply a tautological finding, however. While average wealth is a component in some indices of wellbeing, the PQLI and HUMDEVI indices consider the welfare of poorer groups. Thus, this finding suggests that increasing overall GDP will incidentally benefit the middle class and poorer societal groups as well. This result fundamentally confirms that of others who reached this result with different scales to measure well-being. ${ }^{32}$ 


\section{CONCLUSIONS}

The results suggest that law, wealth, and culture all play a material role in protecting global individual freedoms and promoting material welfare. Culture, presumably, provides a basic level of rights and welfare that plainly differs across the world. European culture is associated with higher levels of individual freedoms. One might suspect this was attributable to Europe's higher level of wealth or rule of law, but the level of freedom is greater than in other regions, even holding those variables constant. The results should not be too unexpected, as individual freedom is in large part a Western construct ${ }^{33}$ and may be ecdemic for other regional cultures. It is perhaps more noteworthy that European nations also have higher levels of material welfare for poorer inhabitants, even holding wealth constant. Several authors suggest that the Western emphasis on individual rights could actually undermine the ability of society communally to provide for its least advantaged, ${ }^{34}$ but that does not appear to be the case in practice. European nations score the same or better on all scales of material well-being.

The results for the effect of law are less clear. Why would lawyers advance political rights much more than civil liberties? Why would lawyers promote overall welfare more than the sort of individual rights that presumably require judicial vindication? Study on the functioning and effects of lawyers in society is plainly inadequate. ${ }^{35}$ Further research on the role of law is needed.

National wealth has a positive effect on both freedom and welfare. A variety of authors have criticized the economists' traditional reliance on GDP as a measure of a nation's well-being, because GDP ignores many important nonmonetized social goods, including liberty. ${ }^{36}$ While this criticism is facially accurate and fair, GDP may incidentally contribute to the growth of such nonmonetized goods and thus be a more adequate measure of welfare than the critics concede. This study suggests that greater levels of national wealth are associated with higher levels of individual freedom and overall human welfare, notwithstanding distributional and other problems of the monetized scale. However, GDP does not exclusively drive freedom and welfare variables, and law and culture remain important.

33. See Bernt, supra note 26. Arat refers to the individualistic negative rights as the "Western model." ARAT, supra note 8, at 8.

34. See sources cited supra notes $9,16$.

35. See, e.g., Ronald J. Gilson, How Many Lawyers Does It Take to Change an Economy?, 17 L. \& SOC. INQUTRY 635 (1992) (lamenting the paucity of rigorous scholarship upon the role of law and lawyers in society).

36. See, e.g., Herbert Hovenkamp, Positivism in Law \& Economics, 78 CAL. L. REv. 815 (1990); Jandhyala Tilak, From Economic Growth to Human Development: A Commentary on Recent Indexes of Development, 19 INT'L J. Soc. ECON. 31 (1992). 
One other important conclusion may be reached, at least tentatively. The purported conflict between negative and positive human rights does not appear. To the contrary, the two types of rights appear associated once one controls for law and wealth. Tables 2 and 4 show that the nations of certain regions are "underachievers" with respect to both positive and negative human rights. Plainly, eschewing individualist negative rights is not necessarily the way to advance positive rights of human welfare.

Finally, an important caveat is in order. This study treats law, wealth, and culture as exogenous factors that determine a society's levels of freedom and welfare. While this seems a reasonably necessary simplifying assumption, reality is somewhat more complex. There undoubtedly exist complex feedback loops through which, for example, greater freedom might increase national wealth or produce a greater role for law. Indeed, the causality might be entirely reversed. Rather than lawyers enhancing material welfare, it is possible that nations with higher levels of material welfare and freedom simply demand more lawyers. Barbara Newman and Randall Thomson suggest such reverse causality between PQLI and GDP, ${ }^{37}$ though Enrico Colombatto challenges this suggestion. ${ }^{38}$ In any event, there remains an important association that suggests the presence of substantial positive externality values of wealth and also suggests the presence of those same values for law and lawyers. Recognition of these values should assist human rights planning and provide additional policy tools for promotion of such rights.

38. Enrico Colombatto, A Comment on Economic Growth and Social Development, 19 WORLD DEV. 1441 (1991). 
